DOI: 10.20472/IAC.2018.043.043

\author{
MARTINA SIPKOVA \\ Metropolitni univerzita Praha, O.P.S., Czech Republic \\ MARIA LEVAKOVA \\ Metropolitan University Prague, Czech Republic, Czech Republic
}

\title{
INDONESIAN BUSINESS ENVIRONMENT - VOC MODEL AND LOCAL CULTURE
}

\begin{abstract}
:
Our presentation focuses on the structure of Indonesian political economy and how local form of capitalism is underpinned by social relations and culture. Specifically, in our research, we: i) analyze Indonesian business environment through the Varieties of Capitalism (henceforth VOC) model as developed by Hall and Soskice, ii) look into the reform and dynamic changes of Indonesian business environment following 1997 crisis in East Asia through the lens of VOC model, and iii) examine how Indonesian form of capitalism is underpinned by local culture by the use of GLOBE Project and Hofstede dimensions of culture. Our findings suggest that the case of Indonesia can be presented as a special type of a coordinated market economy driven by local culture with some aspects of liberal market economy, which are, to a large extent, imported from the outside. Our research also shows that the influence of international business environment and globalization combined with post-1997-crisis reform push Indonesian economy further towards modes of coordination more typical for liberal market economies, causing tensions among various actors of local political economy. Considering limited body of literature on the topic, the main contributions of our research is twofold. First, to study Indonesian form of capitalism, we apply a VOC model and connect local form of capitalism with socio-cultural characteristics of the country. Second, we apply VOC model to look at the interplay between domestic forces shaping local political economy and the influence of international environment and globalization largely reflecting (neo)liberal view of economic and business relations.
\end{abstract}

\section{Keywords:}

Indonesia, business environment, variety of capitalism, Asian Financial Crisis, post-crisis reform, capitalism and culture

JEL Classification: F59, L19, P11 